\title{
Identifikasi Keausan Bantalan Tirus (Tapered Bearing) Berbasis Analisis Vibrasi dengan Metode Support Vector Machine (SVM)
}

\author{
Faisal Rahman Adi dan Suwarmin \\ Departemen Teknik Mesin, Fakultas Teknologi Industri, Laboratorium Otomasi Industri , Institut \\ Teknologi Sepuluh Nopember (ITS) \\ e-mail: suwarmin@gmail.com
}

\begin{abstract}
Abstrak-Data mining memiliki arti kegiatan yang meliputi pengumpulan, pemakaian data historis untuk menemukan keteraturan, pola atau hubungan, dalam set data berukuran besar[1]. Data mining fokus pada prediksi dan deskripsi data. Support Vector Machine (SVM) adalah salah satu teknik dari data mining, digunakan untuk menyelesaikan kasus klasifikasi dan regresi data. SVM mampu mengklasifikasikan data untuk menghasilkan informasi atau pengetahuan baru. Dalam penelitian ini metode SVM digunakan untuk mengidentifikasi keausan pada bantalan tirus (tapered bearing). Data yang digunakan adalah data yang berasal dari pengukuran vibrasi. Pengukuran vibrasi dilakukan pada bantalan yang tidak mengalami keausan (normal) dan bantalan yang mengalami keausan. Keausan pada inner race diamati pada BPFI, keausan pada outer race diamati pada BPFO. Data vibrasi dari kedua bantalan tersebut disatukan menjadi database. Database tersebut dibagi menjadi data testing dan data training. SVM melakukan train untuk proses klasifikasi data, apabila akurasi SVM masih rendah maka dioptimasi dengan mengubah rasio pembagian dari data training dan data testing. Keausan pada bantalan dapat diidentifikasi salah satunya melalui spektrum data vibrasi dimana muncul sideband di daerah BPFO untuk outer race dan BPFI untuk inner race dengan nilai $\pm 1 \times$ FTF. Identifikasi keausan melalui metode SVM menghasilkan model dengan mengumpulnya data BPFI atau BPFO sebagai indikasi terdapat keausan pada bantalan tersebut. Optimasi metode SVM dilakukan dengan metode $K$-fold yang menghasilkan metode SVM dengan keakurasian tertinggi.
\end{abstract}

Kata kunci-analisis vibrasi, keausan bantalan, Support Vector Machine (SVM)

\section{PENDAHULUAN}

$\mathrm{D}$ ALAM dunia industri, perawatan atau maintenance terhadap mesin - mesin dilakukan dengan berbagai teknik. Predictive maintenance merupakan salah satu teknik dari perawatan yang berbasis pada kondisi mesin. Predictive atau condition-based maintenance terdiri dari pemantauan terhadap kondisi mesin dan operasional secara periodik, mengidentifikasi komponen yang bermasalah pada mesin dan melakukan perencaan perawatan, langkah selanjutnya jika diperlukan mesin dimatikan dan komponen yang bermasalah diganti [1]. Analisis vibrasi adalah salah satu metode yang digunakan dalam predictive maintenance, digunakan untuk mengawasi dan menganalisa kondisi kritis dari mesin, komponen, dan sistem pada bagian tertentu berbasis getaran atau vibrasi yang ditimbulkan benda tersebut.

Bantalan merupakan komponen mesin yang berfungsi menahan beban yang ditimbulkan oleh poros. Bantalan dirancang untuk menerima beban aksial dan radial akibat pergerakan poros, salah satu jenis bantalan yang memiliki kemampuan baik dalam menerima beban tersebut adalah jenis tapered roller bearing. Fungsi dari bantalan yang vital membuat bantalan rentan mengalami kegagalan apabila tidak dilakukan sistem perawatan yang baik. Keausan merupakan salah satu jenis kegagalan bantalan yang mampu mengurangi umur bantalan.

Data mining memiliki arti kegiatan yang meliputi pengumpulan, pemakaian data historis untuk menemukan keteraturan, pola atau hubungan, dalam set data berukuran besar [2]. Data mining fokus pada prediksi dan deskripsi data. Support Vector Machine (SVM) adalah salah satu teknik dari data mining, digunakan untuk menyelesaikan kasus klasifikasi dan regresi data. SVM mampu mengklasifikasikan data untuk menghasilkan informasi atau pengetahuan baru.

Berdasarkan uraian diatas didapat gagasan untuk mengidentifikasi keausan bantalan jenis tapered roller bearing berdasarkan data hasil analisis vibrasi melalui salah satu metode data mining yaitu Support Vector Machine (SVM), serta melakukan optimasi metode SVM untuk memperoleh keakuratan yang tinggi dalam klasifikasi data. Tujuan penelitian ini berdasarkan gagasan tersebut adalah:

1. Menganalisis keausan tapered roller bearing melalui bentuk data vibrasi.

2. Mengolah data hasil analisis vibrasi menggunakan prinsip dari data mining.

3. Mengidentifikasi keausan bantalan melalui klasifikasi dari metode Support Vector Machine (SVM).

\section{URAIAN PENELITIAN}

Analisis vibrasi yang merupakan salah satu dari beberapa metode dalam predictive maintenance digunakan untuk mengawasi dan menganalisa kondisi kritis dari mesin, komponen, dan sistem pada bagian tertentu berbasis getaran atau vibrasi yang ditimbulkan benda tersebut. Keuntungan utama menggunakan analisa vibrasi adalah dapat mengidentifikasi masalah sebelum masalah tersebut semakin serius dan menyebabkan perbaikan yang tidak terjadwal, hal tersebut dapat dicapai dengan pemantauan secara berkala pada interval waktu yang terjadwal. Penilaian terhadap kegagalan dari suatu komponen mesin dapat dibaca melalui bentuk data vibrasi domain waktu atau domain frekuensi.

Data Mining, sering disebut knowledge discovery in database (KDD), adalah kegiatan yang meliputi pengumpulan, pemakaian data historis untuk menemukan keteraturan, pola atau hubungan, dalam set data berukuran besar[1]. Dua tujuan utama dalam data mining adalah prediksi dan deskripsi, prediksi menggunakan beberapa 
variabel atau data yang tersedia untuk memprediksikan hal yang belum diketahui atau nilai di masa depan dari beberapa variable lain yang menarik, deskripsi fokus pada menemukan pola dari data yang dapat dijelaskan secara umum.[3]

SVM dapat secara sederhana dijelaskan sebagai usaha mencari hyperplane terbaik yang berfungsi sebagai pemisah dua buah class pada input data [4]. Hyperplane dalam ruang vektor berdimensi- $n$ membagi data pada ruang vektor tersebut ke dalam dua bagian, yang masing-masing data berdekatan pada class yang berbeda.

Skema pada proses analisis vibrasi secara konvensional dapat dilihat pada gambar 1, dalam skema ditunjukkan tahapan - tahapan pada proses analisa vibrasi. Pengukuran dilakukan pada komponen mesin dilakukan dengan tranduscer, tranduscer berfungsi untuk mengukur sinyal vibrasi, data direkam pada Data Acquisition (DAQ) untuk diproses menjadi bentuk data vibrasi. Data vibrasi dalam bentuk domain waktu atau domain frekuensi yang merupakan keluaran dari hasil pengukuran yang telah diproses oleh DAQ, hasil tersebut dibaca untuk melakukan diagnosa terhadap komponen mesin. Pembacaan hasil dan mendiagnosa komponen mesin dilakukan oleh inspektor yang telah berkompeten di bidang analisa vibrasi.

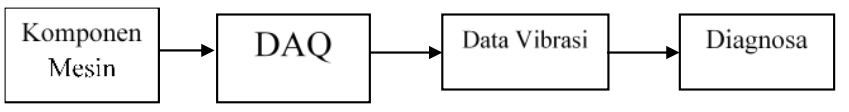

Gambar 1. skema analisis vibrasi konvensional

Analisis vibrasi yang dilakukan dengan cara membaca data vibrasi bentuk domain waktu atau domain fekuensi dari pengukuran, merupakan cara yang konvensional. Inspektor yang ditunjuk untuk membaca data vibrasi dari pengukuran dan mendiagnosa komponen tersebut harus memiliki keahlian, hal ini menyebabkan kemungkinan terjadinya perbedaan persepsi dalam pembacaan data vibrasi.

Support Vector Machine (SVM) menawarkan konsep dalam mendiagnosa secara konsisten, artinya hasil dari diagnosa yang dilakukan siapapun dapat sama. Skema analisis vibrasi dengan SVM ditunjukkan pada gambar 2, metode SVM yang digunakan diletakkan setelah didapatnya data vibrasi hasil proses pada DAQ. Data vibrasi tersebut disusun agar dapat diolah menggunakan perangkat lunak dengan metode SVM. Hasil pengolahan data dengan metode SVM dan ditampikan dalam bentuk pola atau plot data, pola tersebut digunakan untuk mengklasifikasikan data berdasarkan kriteria atau label yang telah ditentukan, sehingga dapat didiagnosa atau diambil kesimpulan terhadap kondisi komponen mesin tersebut.

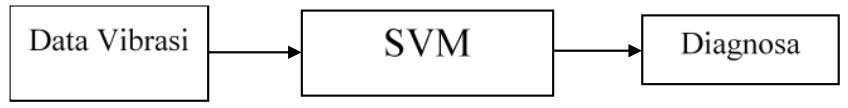

Gambar 2. skema analisis vibrasi dengan SVM

Kelebihan menggunakan metode SVM dalam analisis vibrasi adalah kesamaan diagnosa dari proses analisa terhadap kondisi komponen mesin yang dilakukan oleh inspektor. Metode SVM ini juga berlaku berkelanjutan, artinya dalam sekali proses analisis vibrasi data tersebut akan terekam sebagai database dan dapat digunakan untuk analisis vibrasi di waktu lain.

Penelitian ini dilakukan pada dua produk tapered bearing yaitu Koyo dan Timken dengan jenis 30304. Alat uji atau test bench dapat dilihat pada gambar 3 .

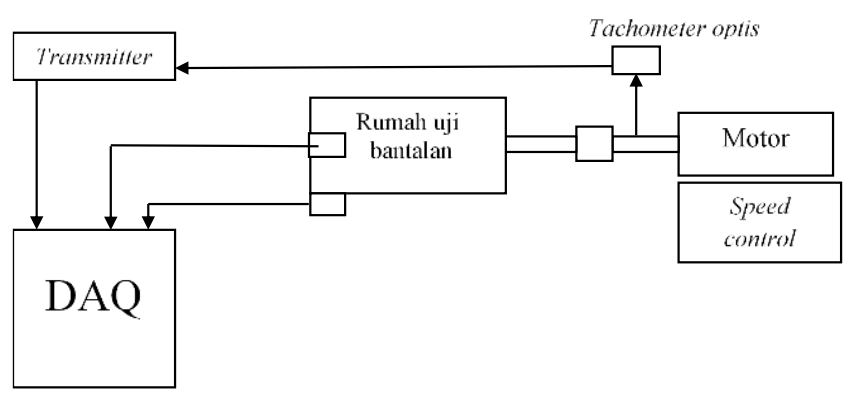

Gambar 3. skema penyusunan alat analisis vibrasi

Pengukuran vibrasi dilakukan dengan menggunakan alat DAQ device model CSI 2120A Duak Channel, Thacometer optis model 404B Infrared Phototach dengan tegangan 5-15 VDC dan dilengkapi dengan Transmitter, Accelerometer model PCB Pieztronic Accelerometer 2 unit dengan sensitifitas 0.0989 untuk vertikal dan 0.1011 untuk horizontal, Motor dengan daya 1/12 HP tegangan 180 VDC dan dilengkapi dengan pengatur kecepatan, serta alat uji penunjang berupa rumah uji bantalan, poros, dan kopling.

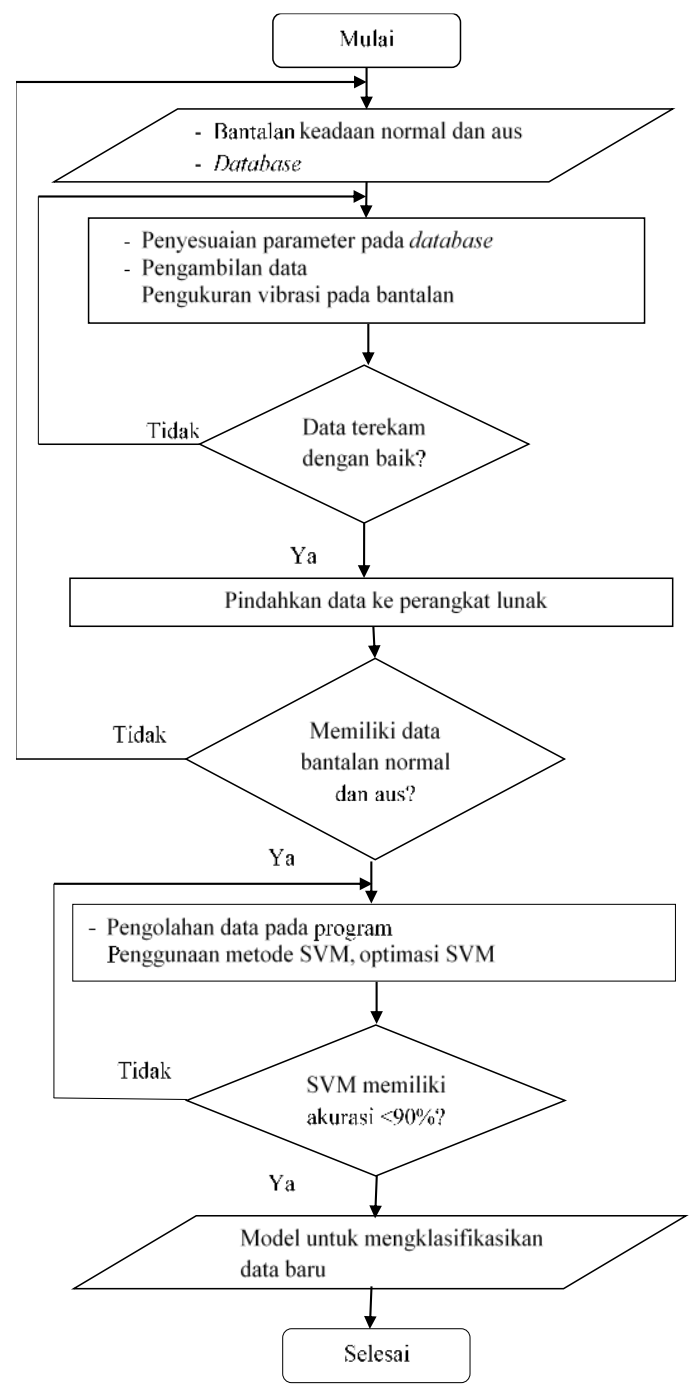

Gambar 4. diagram alir pengujian 


\section{ANALISIS DAN PEMBAHASAN}

A. Analisa keausan tapered roller bearing melalui data vibrasi

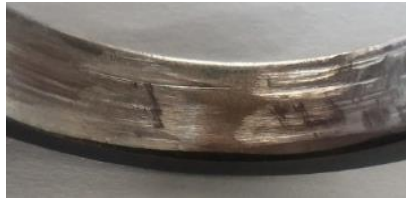

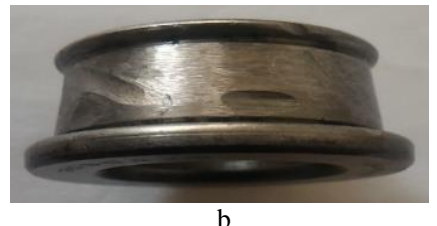

b
Gambar 5. keausan yang terjadi di outer race (a) dan inner race (b)

Bentuk keausan pada bantalan dapat dilihat pada gambar 5 a untuk outer race dan gambar $5 b$ untuk inner race. Spektrum hasil pengukuran vibrasi dari bantalan tersebut berupa:

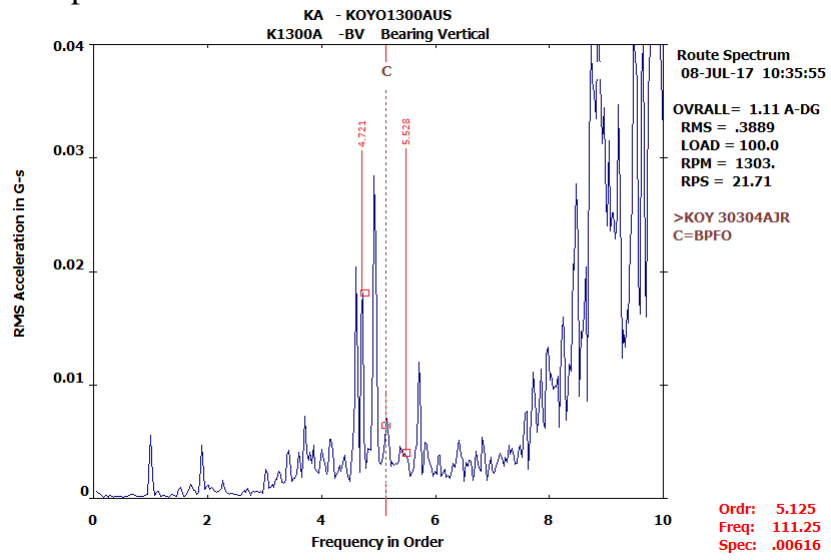

Gambar 6. spektrum vibrasi dengan nilai 1x BPFO dan sideband pada bantalan Koyo yang mengalami keausan

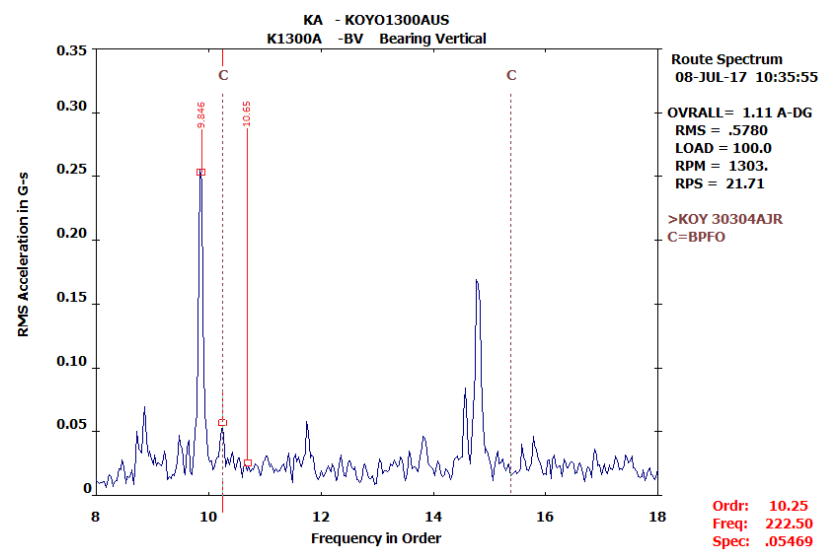

Gambar 7. spektrum vibrasi dengan nilai 2x BPFO dan sideband pada bantalan Koyo yang mengalami keausan

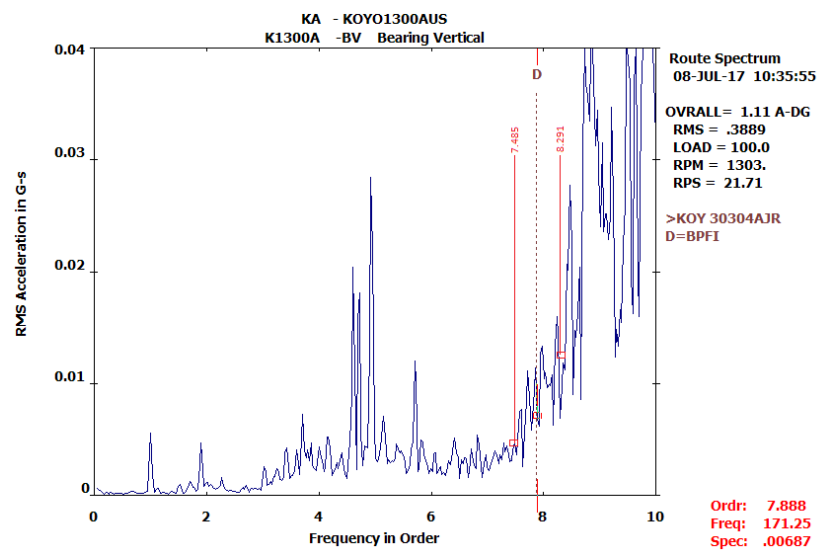

Gambar 8. spektrum vibrasi dengan nilai 1x BPFI dan sideband pada bantalan Koyo yang mengalami keausan

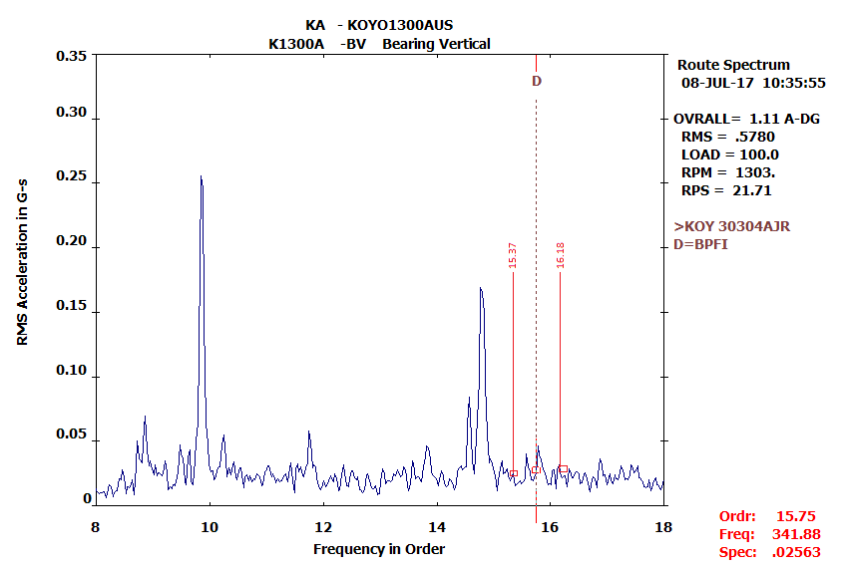

Gambar 9. spektrum vibrasi dengan nilai 2x BPFI dan sideband pada bantalan Koyo yang mengalami keausan

Berdasarkan gambar 6 sampai 9, sideband yang muncul disekitar frekuensi refrensi merupakan salah satu indikasi bantalan mengalami keausan. Letak sideband pada outer race diketahui melalui BPFO \pm FTF dan pada inner race diketahui melalui BPFI \pm FTF.

\section{B. Identifikasi keausan melalui metode SVM}

Proses pengolahan data vibrasi menggunakan metode SVM dimulai dari data vibrasi amplitudo, order dan class awal hingga dapat dilakukan klasifikasi untuk data baru. Input berupa amplitudo, order, dan class untuk setiap metode SVM dibuat model 1 untuk mengetahui tingkat akurasinya. Looping atau pengulangan terhadap metode SVM dilakukan yang bertujuan mencari metode terbaik untuk mengklasifikasikan data vibrasi. Pembuatan model 1 untuk setiap metode dilakukan berulang dengan teknik $K$-fold. Model 2 digunakan untuk evaluasi dan optimasi dari model 1. Model 2 adalah model 1 metode SVM yang memiliki keakurasian tertinggi. Akurasi dari model 2 lebih tinggi daripada model 1 dan model 2 dapat dijadikan model untuk melakukan klasifikasi terhadap data baru. Model 3 dibuat untuk menilai keakurasian dari klasifikasi model 2 . Pembacaan hasil klasifikasi berupa model 3 merupakan output dari proses pengolahan data.

Data baru sebagai validasi model 2 identifikasi keausan bantalan dengan metode SVM dilakukan dengan 4 kasus yaitu bantalan Koyo yang mengalami keausan inner race dan outer race normal, bantalan Koyo dengan inner race normal dan outer race mengalami keausan, bantalan Timken yang mengalami keausan outer race dan inner race dalam keadaan normal, serta bantalan Timken yang mengalami cacat lokal pada outer race dan inner race dalam keadaan normal. Hasil model dari kasus bantalan Koyo yang mengalami keausan inner race dan outer race normal.

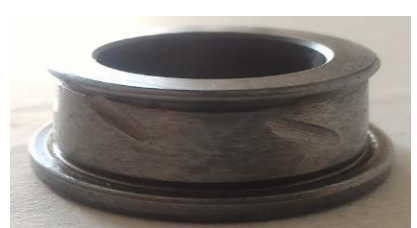

a

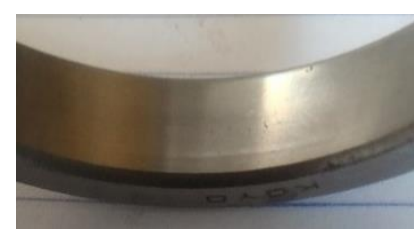

b
Gambar 10. bantalan Koyo bagian inner race mengalami keausan (a) dan outer race dalam keadaan normal (b)

Beberapa class pada gambar 11 dapat dihilangkan dan menghasilkan gambar 12 untuk memudahkan membaca hasil identifikasi. Pada gambar 12 terlihat banyak data berwarna biru atau data BPFI yang mengumpul, hal tersebut 
menandakan bahwa bantalan yang dianalisis vibrasinya terdapat keausan pada inner race. Data misaligment yang berwarna biru muda tidak muncul pada model, ini menandakan bantalan tersebut tidak memiliki gejala misalignment. Data BPFO yang berwarna jingga muncul dengan jumlah yang sedikit dan tinggal mengumpul menandakan bantalan tersebut tidak memiliki gejala keausan pada outer race. Data normal yang berwarna merah marun sedikit muncul menandakan bantalan dalam kondisi ini mendekati akhir umur dan selayaknya diganti.

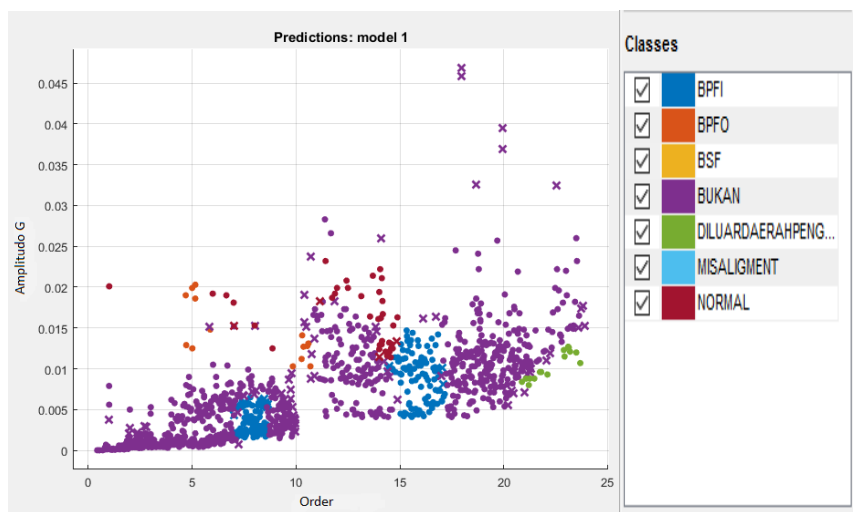

Gambar 11. klasifikasi bantalan Koyo yang mengalami keausan pada inner race dengan keakuratan $91.9 \%$

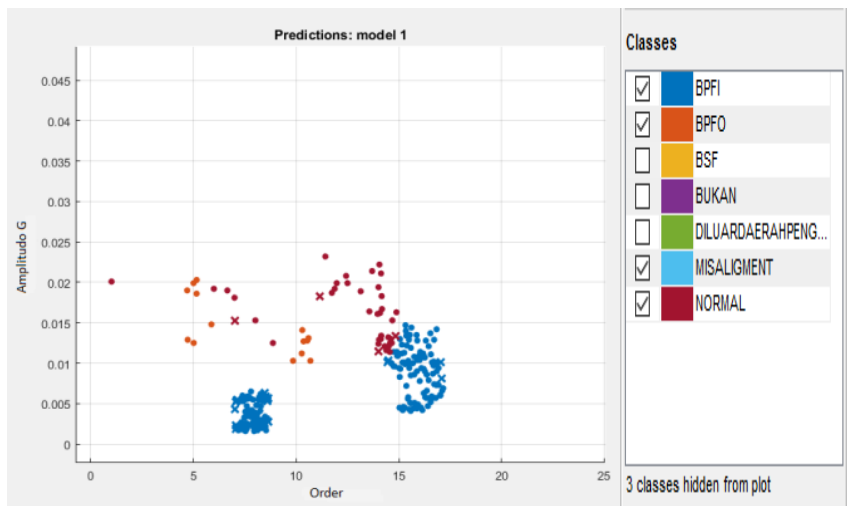

Gambar 12. hasil klasifikasi bantalan Koyo yang mengalami keausan pada inner race dengan menghilangkan beberapa class

\section{KESIMPULAN}

Kesimpulan dari penelitian ini adalah:
1. Sideband yang muncul disekitar frekuensi refrensi merupakan salah satu indikasi bantalan mengalami keausan. Letak sideband pada outer race diketahui melalui $\mathrm{BPFO} \pm \mathrm{FTF}$ dan pada inner race diketahui melalui BPFI \pm FTF.

2. Metode SVM yang paling tepat digunakan dalam penelitian ini dari ke-6 metode SVM untuk identifikasi keausan bantalan adalah Fine Gaussian SVM dengan nilai $K$-fold $=10$, karena memiliki keakurasian tertinggi yaitu $83 \%$.

3. Identifikasi keausan pada data baru menghasilkan klasifikasi koyo aus inner race dengan keakuratan $91.9 \%$, klasifikasi koyo aus outer race dengan keakuratan 95\%, klasifikasi Timken aus outer race dengan keakuratan 94.2\%, dan klasifikasi Timken cacat lokal outer race dengan keakuratan $93.5 \%$.

4. Tiga dari empat kasus menampilkan data keausan pada inner race yang sebenarnya tidak aus, hal tersebut memberi arti bahwa kerusakan pada outer race memiliki kecenderungan akan cepat berdampak pada inner race.

5. Pada kasus ke-2 yaitu Koyo yang mengalami keausan pada outer race, tidak ditemukan data class normal, menandakan bahwa pada kondisi tersebut bantalan sudah saatnya untuk diganti. Kasus pertama yaitu untuk Koyo yang mengalami keausan pada inner race data class normal muncul sedikit yang artinya bantalan mendekati masa habis umurnya maka layaknya segera diganti. Kasus ke-3 dan ke-4 yaitu Timken yang mengalami keausan pada outer race dan kecacatan pada outer race masih dapat digunakan karena data class normal masih terdapat banyak.

\section{DAFTAR PUSTAKA}

[1] and D. J. Dolenc, Bostjan, Pavle Bosloski, "Distributed Bearing Fault Diagnosis Based on Vibration Analysis," Mechenical Syst. Signal Process. 66-67, pp. 521-532, 2015.

[2] B. Santosa, Data Mining: Teknik Pemanfaatan Data untuk Keperluan Bisnis. Yogyakarta: Graha Ilmu, 2007

[3] M. Kantardzid, Data Mining: concepts, models, methods, and algorithm 2nd edition. United State of America: John Wiley \& Sons, Inc, 2011.

[4] dan D. H. Nugroho, Anto S., Arief Budi W., "Support Vector Machine "Teori dan Aplikasinya dalam Bioinformatika," IlmuKomputer.Com, 2003. 